\title{
KEMAMPUAN PEGAWAI DALAM PENGINPUTAN DATA E-KTP DI KANTOR CAMAT TIBAWA KABUPATEN GORONTALO
}

\author{
Nunung Tawa'a \& Andi Yusuf Katili \\ STIA Bina Taruna Gorontalo \\ bukujurnalstia@binataruna.ac.id ${ }^{1} \&$ yusuf2801@gmail.com ${ }^{2}$
}

\begin{abstract}
ABSTRAK
Penelitian ini bertujuan untuk mengetahui Kemampuan Pegawai dalam Penginputan Data E-KTP di Kantor Camat Tibawa Kabupaten Gorontalo. Dengan fokus penelitian yaitu kecakapan, keterampilan, pengalaman, dan kesungguhan. Penelitian ini menggunakan jenis penelitian deskriptif kualitatif. Teknik pengumpulan data yang digunakan adalah: Observasi, Wawancara dan Dokumentasi. Teknik analisis data adalah teknik analisis kualitatif.

Hasil penelitian menunjukkan bahwa dilihat baik dari aspek kecakapan, keterampilan, pengalaman maupun aspek kesungguhan masih rendah atau belum menunjang kemampuan pegawai dalam penginputan data E-KTP.

Adapun hal-hal yang disarankan dalam penelitian ini yakni perlunya pegawai meningkatkan kecakapannya dalam melaksanakan tugasnya, agar pelayanan penginputan data E-KTP yang dilakukan oleh pegawai lebih efektif dilaksanakan. Perlunya pegawai dapat meningkatkan keterampilan melalui pelatihan-pelatihan dan lokakarya yang diikutinya, agar-tugas-tugas organisasi agar pelayanan penginputan data E-KTP lebih optimal. Perlunya pegawai dapat meningkatkan pengalamaannya, dengan mengikuti berbagai kegiatan yang berhubungan dengan pengelolaan data atau penginputan data E-KTP, agar tugas yang diembannya lebih maksimal dilakukan. Diharapkan kepada Pemerintah Kecamatan untuk dapat memperhatikan hal-hal yang mendukung terselenggaranya pelayanan penginputan data E-KTP yang berkualitas, terutama yang berhubungan dengan kemampuan yang dimiliki oleh pegawai agar tidak terjadi pandangan negatif dari masyarakat terhadap pelayanan penginputan data E-KTP yang dilakukan oleh pegawai.
\end{abstract}

\section{Kata Kunci: Kemampuan; Penginputan Data; E-KTP}

\section{PENDAHULUAN}

Satu hal belakangan ini sering dipermasalahkan adalah pembuatan Elektronik Kartu Tanda Penduduk (EKTP), terutama dalam hal kualitas atau mutu pelayanan aparatur pemerintah kepada masyarakat. Pelayanan publik yang berkualitas atau pelayanan prima dapat dilakukan dengan baik manakala didukung oleh kinerja yang baik dan berkualitas dari pegawai sebagai aparat pemerintah pemberi layanan. Pegawai dikatakan memiliki kinerja yang baik apabila mereka memilki peran aktif dalam bekerja, baik itu peran mereka dalam pembangunan dan pelayanan pada masyarakat, maupun dalam memberikan motivasi kepada seluruh komponen yang ada untuk 
memberikan pelayanan yang berkualitas. Aparatur pemerintah harus menjadi panutan bagi seluruh masyarakat. Dengan pemanfaatan waktu sebaik-baiknya dengan orientasi hasil yang semaksimal mungkin dalam pelayanan publik. Aparatur juga harus mampu melaksanakan pekerjaannya dengan baik dalam rangka memberikan pelayanan prima kepada masyarakat. Untuk itu dituntut kualitas sumber daya pegawai yang baik dan berkompeten di bidangnya.

Potensi sumber daya manusia (pegawai) pada hakikatnya merupakan salah satu modal dasar dalam mencapai tujuan bersama baik pemerintah maupun masyarakat. Namun selama ini masih dirasakan bahwa potensi pegawai tersebut belum dapat dimanfaatkan secara optimal mengingat sebagian besar angkatan kerja, tingkat keterampilan dan pendidikannya masih rendah, hal ini berakibat pula pada rendahnya kinerja pegawai sebagai aparatur pemerintah dan seterusnya akan mengakibatkan pula rendahnya tingkat pelayanan yang diberikan kepada masyarakat.

Persoalan kualitas kerja pegawai dan pelayanan publik menjadi persoalan yang sering dibahas di berbagai instansi pemerintah, demikian halnya di Kantor Camat Tibawa, sebagai instansi yang bergerak di bidang pelayanan administrasi sekaligus penginputan data E-KTP, pegawainya dituntut untuk memberikan kualitas kerja yang baik dalam rangka memberikan pelayanan publik yang berkualitas. Tetapi harapan ini belum sesuai dengan harapan dan keinginan serta kebutuhan masyarakat hingga saat ini.
Undang-Undang RI Nomor 23 tahun 2006 mengenai Administrasi Kependudukan dan Peraturan Presiden nomor 26 tahun 2009 mengenai penerapan E-KTP yang berbasis dari Nomor Induk Kependudukan (NIK) merupakan dasar hukum pembuatan atau penerbitan E-KTP. Sesuai ketentuan bahwa "setiap penduduk hanya diperkenankan mempunyai 1 (satu) KTP. Di Kecamatan Tibawa sendiri bahwa pelaksanaan E-KTP dicanangkan pada tahun 2010 oleh Bupati Kabupaten Gorontalo, dengan melibatkan tiga kecamatan yang ada di Kabupaten Gorontalo seperti Kecamatan Limboto Barat, Kecamatan Bongomeme dan Kecamatan Dungaliyo.

Hasil penelitian di Kantor Camat Tibawa Kabupaten Gorontalo menunjukkan bahwa penginputan data E-KTP belum optimal dilakukan, hal ini terjadi karena masih ada beberapa kendala yaitu penginputan E-KTP belum berjalan seperti apa yang diharapkan. Belum efektifnya pengimputan data E-KTP di Kantor Camat Tibawa karena diakibatkan oleh sumber daya pegawai atau petugas masih rendah, baik dilihat dari aspek kecakapan, keterampilan, pengalaman, dan kesungguhan. Kecakapan pegawai masih tergolong rendah, hal ini dapat dilihat dari proses penginputan data E-KTP seringkali mengalami keterlambatan sehingga banyak masyarakat yang mengeluh dengan pelayanan yang diberikan oleh pegawai. Misalnya dari 5,678 orang yang wajib mengurus atau mendapatkan pelayanan E-KTP oleh aparat yang ada di Kantor Camat Tibawa, yang dapat diselesaikan baru sekitar 4,590 orang, artinya masih ada 


\section{METODE PENELITIAN}

Penelitian menggunakan jenis deskriptif pendekatan kualitatif. Penelitian deskriptif pendekatan kualitatif, menurut Bogdan dan Taylor (dalam Moleong, 2014:3), sebagai prosedur penelitian yang menghasilkan data deskriptif berupa kata-kata tertulis atau lisan dari orangorang dari perilaku yang dapat diamati.

Menurut Nawawi (2009:67) bahwa metode deskriptif dapat diartikan sebagai prosedur pemecahan masalah yang diselidiki dengan menggambarkan/ melukiskan keadaan subyek/obyek penelitian (seseorang, lembaga, masyarakat dan lain-lain) pada saat sekarang berdasarkan faktafakta yang tampak, atau sebagaimana adanya.

\section{Fokus Penelitian}

Penelitian ini difokuskan pada Kemampuan Pegawai dalam Penginputan Data Elektronik Kartu Tanda Penduduk (E-KTP), yang pendalamannya akan dilihat dari segi kecakapan, keterampilan, pengalaman, dan kesungguhan yang secara operasional dideskripsikan sebagai berikut:

Kecakapan yaitu, kemampuan atau daya tanggap yang dimiliki oleh pegawai untuk menunjang pelaksanaan tugas organisasi demikian pula dalam penginputan data E-KTP; Keterampilan yaitu, keahlian yang dimiliki oleh pegawai untuk menunjang pelaksanaan tugas organisasi, demikian pula dalam penginputan data Elektronik Kartu Tanda Penduduk (E-KTP);
Pengalaman yaitu, masa kerja atau masa tugas yang dimiliki oleh pegawai dalam mendukung pelaksanaan pekerjaan, termasuk pengimputan data Elektronik Kartu Tanda Penduduk (EKTP).

Kesungguhan yaitu keteguhan hati yang tinggi yang dimiliki oleh pegawai dalam melakukan sebuah pekerjaan tanpa pamrih, termasuk melaksanakan tugas penginputan data Elektronik Kartu Tanda Penduduk (EKTP).

\section{HASIL PENELITIAN DAN PEMBAHASAN}

\section{Kecakapan}

Kecakapan merupakan salah satu kemampuan seseorang dalam menyelesaikan suatu pekerjaan. Dan kecakapan yang dimaksud dalam penelitian ini yaitu kemampuan atau daya tanggap yang dimiliki oleh pegawai untuk menunjang pelaksanaan tugas organisasi dalam penginputan data E-KTP.

Hasil penelitian menunjukkan bahwa Kemampuan Pegawai Dalam Pengimputan Data Elektronik Kartu Tanda Penduduk E-KTP di Kantor Camat Tibawa Kabupaten Gorontalo yang dilihat dari aspek kecakapan masih rendah atau belum menunjang. Hal ini terjadi karena proses penginputan data Elektronik Kartu Tanda Penduduk (E-KTP) seringkali mengalami keterlambatan sehingga banyak masyarakat yang mengeluh dengan pelayanan yang diberikan oleh pegawai di Kantor Camat Tibawa Kabupaten Gorontalo. 


\section{Keterampilan}

Keterampilan adalah juga suatu kemampuan dari seseorang dalam menyelesaikan pekerjaan yang ditugaskan kepadanya. Dan keterampilan yang dimaksud dalam penelitian ini adalah keterampilan dalam menjalankan

Hasil penelitian menunjukkan bahwa Kemampuan Pegawai Dalam Pengimputan Data Elektronik Kartu Tanda Penduduk E-KTP di Kantor Camat Tibawa Kabupaten Gorontalo yang dilihat dari aspek ktrampilan masih rendah atau belum menunjang. Hal ini terjadi karena ketrampilan yang dimiliki oleh pegawai masih kurang atau masih terbatas, hal tersebut dapat ditunjukan dari proses pengimputan data masih banyak mengalami kesalahan dan selalu dilakukan berulang-ulang, kondisi tersebut sangat mempengaruhi pengimputan data E-KTP kurang maksimal dilakukan di Kantor Camat Tibawa Kabupaten Gorontalo.

\section{Pengalaman}

Pengalaman adalah suatu proses yang dialami oleh seseorang dalam suatu masa kerja atau masa tugas yang dimiliki oleh pegawai dalam mendukung pelaksanaan pekerjaan

Hasil penelitian menunjukkan bahwa Kemampuan Pegawai Dalam Pengimputan Data E-KTP di Kantor Camat Tibawa Kabupaten Gorontalo yang dilihat dari aspek pengalaman masih kurang atau belum menunjang. Hal ini terjadi karena pegawai yang dipekerjakan di bagian penginputan data E-KTP masa kerjanya belum satu tahun, dan belum pernah diikutkan dalam pelatihan-pelatihan yang berhubungan dengan penginputan data kependudukan, sehingga banyak tugas-tugas organisasi termasuk penginputan data E-KTP kurang maksimal dilakukan di Kantor Camat Tibawa.

\section{Kesungguhan}

Kesungguhan adalah keteguhan hati yang tinggi yang dimiliki oleh pegawai dalam melakukan sebuah pekerjaan tanpa pamrih. Dan kesungguhan yang dimaksud dalam penelitian adalah kesungguhan dalam melaksanakan tugas penginputan data EKTP.

Hasil penelitian menunjukkan bahwa Kemampuan Pegawai Dalam Pengimputan Data E-KTP di Kantor Camat Tibawa Kabupaten Gorontalo yang dilihat dari aspek kesungguhan pegawai masih rendah atau belum menunjang. Hal ini terjadi karena pegawai yang bertugas di bagian penginputan data E-KTP adalah tenaga honorer, yang menerima insentif 5 ratus ribu rupiah perbulannya, sehingga jumlah yang diterima tidak sebanding dengan beban kerja yang dilaksanakannya, sehingga faktor tersebut sangat mempengaruhi tugas yang dilaksanakannya di Kantor Camat Tibawa Kabupaten Gorontalo.

\section{KESIMPULAN}

Berdasarkan hasil penelitian dan pembahasan yang telah diuraikan, maka hasil penelitian ini dapat disimpulkan sebagai berikut:

1. Dilihat dari aspek kecakapan masih rendah atau belum menunjang. Hal ini terjadi karena proses penginputan data E-KTP seringkali mengalami keterlambatan sehingga 
banyak masyarakat yang mengeluh dengan pelayanan yang diberikan oleh pegawai di Kantor Camat Tibawa.

2. Dilihat dari aspek ktrampilan masih rendah atau belum menunjang. Hal ini terjadi karena ketrampilan yang dimiliki oleh pegawai masih kurang atau masih terbatas, hal tersebut dapat ditunjukan dari proses pengimputan data masih banyak mengalami kesalahan dan selalu dilakukan berulang-ulang, kondisi tersebut sangat mempengaruhi pengimputan data E-KTP kurang maksimal dilakukan di Kantor Camat Tibawa.

3. Dilihat dari aspek pengalaman masih kurang atau belum menunjang. Hal ini terjadi karena pegawai yang dipekerjakan di bagian penginputan data E-KTP masa kerjanya belum satu tahun, dan belum pernah diikutkan dalam pelatihan-pelatihan yang berhubungan dengan penginputan data kependudukan, sehingga banyak tugas-tugas organisasi termasuk penginputan data E-KTP kurang maksimal dilakukan.

4. Dilihat dari aspek kesungguhan pegawai masih rendah atau belum menunjang. Hal ini terjadi karena pegawai yang bertugas di bagian penginputan data E-KTP adalah tenaga honorer, yang menerima insentif 5 ratus ribu rupiah perbulannya, sehingga jumlah yang diterima tidak sebanding dengan beban kerja yang dilaksanakannya, sehingga faktor tersebut sangat mempengaruhi tugas yang dilaksanakannya.

Secara umum penelitian menunjukkan bahwa Kemampuan
Pegawai Dalam Pengimputan Data Elektronik Kartu Tanda Penduduk (EKTP) di Kantor Camat Tibawa Kabupaten Gorontalo yang dilihat dari aspek kecakapan, ketrampilan, pengalaman, dan kseungguhan masih rendah atau kurang menunjang.

\section{SARAN}

Sehubungan dengan kesimpulan hasil penelitian yang diuraikan tersebut di atas, perlu disarankan sebagai berikut:

1. Perlunya pegawai meningkatkan kecakapannya dalam melaksanakan tugasnya, agar pelayanan penginputan data E-KTP yang dilakukan oleh pegawai lebih efektif dilaksanakan.

2. Perlunya pegawai dapat meningkatkan ketrampilan melalui pelatihan-pelatihan dan lokakarya yang diikutinya, agar tugas-tugas organisasi, termasuk pelayanan penginputan data E-KTP yang dilakukan oleh pegawai atau petugas lebih optimal dilaksanakan.

3. Perlunya pegawai dapat meningkatkan pengalamaannya, dengan mengikuti berbagai kegiatan yang berhubungan dengan pengelolaan data atau penginputan data E-KTP, agar tugas yang diembannya lebih maksimal dilakukan.

4. Diharapkan kepada Pemerintah Kecamatan untuk dapat memperhatikan hal-hal yang mendukung terselenggaranya pelayanan penginputan data E-KTP yang berkualitas, terutama yang berhubungan dengan kemampuan yang dimiliki oleh pegawai agar 
PUBLIK: Jurnal Manajemen Sumber Daya Manusia, Administrasi dan Pelayanan Publik Sekolah Tinggi Ilmu Administrasi Bina Taruna Gorontalo Volume VI Nomor 1 Juni 2019

tidak terjadi pandangan negatif dari masyarakat terhadap pelayanan penginputan data E-KTP yang dilakukan oleh pegawai.

\section{DAFTAR PUSTAKA}

Creswell, John W. 2010. Research Design, Pendekatan Kualitatif Kuantitatif, dan Mixed. Edisi Ketiga, Cetakan Pertama, Yogyakarta: Pustaka Pelajar.

Hasibuan, H. Melayu S.P. 2009, Manajemen, Dasar, Pengertian, dan Masalah, Edisi Revisi, Cet. Keenam, Jakarta: PT. Bumi Aksara.

Mangkunegara, A.A.A. Prabu, 2009. Manajemen Sumber Daya Manusia Perusahaan. Bandung: PT. Rosda Karya.

Moleong, J, Lexy. 2014. Metode Penelitian Kualitatif. Bandung: PT. Remaja Rosdakarya

Moenir, 2009. Kinerja Organisasi \& Reformasi Pelayanan Publik, Jakarta: Bumi Aksara.

Nafarin, M. 2011. Pengantar Teori Manajemen dan Administrasi. Jakarta: Grasindo.

Nawawi, Handari. 2009. Manajemen Sumber Daya Manusia, cetakan ketiga. Yogyakarta: Gama Press. 2008. Manajemen Strategik Organisasi Non Profit Bidang Pemerintahan, Yogyakarta : Gajah Mada University Press 2009. Metode Penelitian Bidang Sosial. Yogyakarta: Gadjah Mada University.

Pasolong, Harbani. 2013. Teori Administrasi Publik. Cetakan ke5. Bandung: Alfabeta.
Poerwadarminta. 2008. Kamus Besar Bahasa Indonesia, Jakarta: Pusat Pengembangan Bahasa Depdikbud.

Ratminto, Winarsih. 2011. Kualitas Pelayana Publik dalam Organisasi Pemerintah. Jakarta: Binarupa Aksara.

Riduwan. 2010. Metode \& Teknik Menyusun Tesis. Pengantar Kata Buchari Alma, Cet. Ketiga. Bandung: Alfabeta.

Rivai, Vethzal. 2014. Pemimpin dan Kepemimpinan Dalam Organisasi. Jakarta: PT RajaGrafindo Persada.

Saputroa. G. Marwan. Asri. 2010. Management Control System. Jakarta: Salemba Empat.

Saputro dan Asri, 2010. Manajemen Pemasaran. Yogyakarta: BPFE

Siagian, S.P. 2010. Organisasi Kepemimpinan dan Perilaku Administrasi. Jakarta: Gunung Agung. 2008. Filsafat Administrasi. Jakarta: Gunung Agung.

Sianipar, S. A. 2010. Mutu Pelayanan dalam Organisasi Sektor Publik. Jakarta: PT. Raja Grafindo.

Sulistiyani, Ambar Teguh dan Rosidah. 2011. Manajemen Sumber Daya Manusia: Konsep, Teori dan Pengembangan dalam Konteks Organisasi Publik. Yogyakarta: Graha Ilmu.

Sulistiyani, Ambar Teguh (editor). 2009. Memahami Good Governance Dalam Perspektif Sumber Daya Manusia, Yogyakarta: Gaya Media. 